\title{
Scrisul epistolar românesc: o perspectivă cultural-retorică (II)
}

\author{
Gabriela-Iuliana Morcov ${ }^{1}$, Ioan Milică ${ }^{2 *}$ \\ ${ }^{1}$ Şcoala Doctorală de Studii Filologice, Universitatea „Alexandru Ioan Cuza", Bd. Carol I 11, 700506 Iași, România \\ ${ }^{2}$ Facultatea de Litere, Universitatea „Alexandru Ioan Cuza", Bd. Carol I 11, 700506 Iași, România
}

\author{
Despre articol \\ Istoric: \\ Primit 23 martie 2016 \\ Acceptat 12 aprilie 2016 \\ Publicat 1 august 2016 \\ Cuvinte-cheie: \\ scrisoare \\ retorică \\ funcționalism \\ stilul epistolar românesc
}

\begin{abstract}
Rezumat
Articolul se concentrează asupra particularităților ce definesc scrisul epistolar românesc în perioada sa de formare și de consolidare. Analiza structurii și trăsăturilor stilistice ale textului epistolar are în vedere compoziția vechilor documente românești, în conformitate cu standardele impuse de formularul creat după model slavon, dar și raportarea textelor vechi la doctrina celor trei ipostaze ale elocuției - stilul simplu, stilul moderat și stilul înalt. Descrierea vechiului stil epistolar românesc este întregită prin propunerea unei clasificări funcționale a documentelor pe baza modelului comunicativ dezvoltat de Roman Jakobson (1964); într-un cadru delimitat de cei șase factori ai comunicării, scrierile epistolare sînt organizate în diferite categorii, în funcție de aparteneța socio-culturală a emițătorului și de competența comunicativă a acestuia și, respectiv, a receptorului, precum și în funcție de raportarea mesajului epistolar la context, la codul lingvistic utilizat și la specificul canalului comunicativ.
\end{abstract}

„Cum trebuie să fie o conversație? Desluşită și lesnicioasă. Acestea sînt și cele două calități ale stilului epistolar." C. Donescu, Epistolariu culesu shi întocmitu asfelu..., 1840

\section{Stilul epistolar românesc: o analiză retorică}

\subsection{Structura și trăsăturile stilistice ale textului epistolar}

Redactarea epistolelor în limba slavonă sau în alte limbi de circulație diplomatică a restrîns aria de întrebuințare a acestora, făcîndu-le accesibile doar unor categorii sociale privilegiate: domni, prelați, mari dregători sau boieri. Chiar și în perioada care atestă o intensificare a obiceiului redactării în limba poporului, scrisoarea va continua să fie cultivată cu precădere de cei învățați. Arhivele ne arată că emitenții epistolelor din preajma veacului al XVII-lea provin și din categoriile de oameni simpli, neinstruiți, însă reușita demersului lor interactiv este de cele mai multe ori condiționată de intervenția scribilor. Pe lîngă rolul practic al activității lor, acela de a face posibilă transmiterea mesajelor în formă scrisă, trebuie semnalată și contribuția pe care acești profesioniști ai scrisului (logofeți, dieci, preoți, boieri învăţaţi) au avut-o la stabilirea și circulația unei formularistici generale în epocă.

Pentru perioada secolelor al XVI-lea și al XVII-lea normele de redactare sînt cele impuse de cancelariile domnești, motiv pentru care formularistica epistolară, creată după model slavon, este relativ unitară și nu se distinge fundamental de tiparul actelor sau al altor texte cu caracter juridic sau administrativ. Orice document al vremii cuprinde riguros trei mari diviziuni-protocolul inițial, contextul și protocolul finalşi elementele componente corespunzătoare (v. Tabela 1) pe care Alexandru Mareș le prezintă detaliat în studiul introductiv al lucrării Documente și însemnări românești din secolul al XVI-lea. Scrisoarea păstrează doar o parte dintre aceste elemente. În diferite situații de comunicare, în funcție de scopul urmărit și de strategiile pe care se mizează, unele componente pot lipsi, pot fi formulate convențional sau, dimpotrivă, pot fi elaborate într-o notă solemnă, reverențioasă sau familiară.

\footnotetext{
*Adresă de corespondență: ioanister@gmail.com.
} 


\begin{tabular}{l|c} 
Protocolul inițial & $\begin{array}{c}\text { invocația simbolică (verbală) } \\
\text { intitulația } \\
\text { adresa } \\
\text { salutația }\end{array}$ \\
\hline Contextul & $\begin{array}{c}\text { notificația } \\
\text { expoziția } \\
\text { dispoziția }\end{array}$ \\
& *clauza prohibitivă (aceasta nu este o componentă \\
independentă a contextului, ci parte a dispoziției) \\
sancțiunea \\
coroborația
\end{tabular}

Tabela 1: Formularul documentelor românești în epoca veche (Chivu et al., 1979, p. 35-47)

Componentele protocolului inițial ce caracterizează scrisorile sînt, în primul rînd, adresa / inscripțtia, alcătuită din numele, titlul și calitatea destinatarului, și salutația. De asemenea, în ceea ce privește contextul, epistolei îi sînt comune doar o parte dintre elementele ce definesc structura documentelor oficialadministrative. Notificația este exprimată în general prin formula dau (dăm) în știre și este urmată de obicei de expoziţie - componentă ce cuprinde relatarea evenimentelor și împrejurărilor care formează obiectul documentului. Dispoziția, clauza probibitivă, sancțiunea și coroborația nu sînt elemente specifice contextului scrisorii, însă unele dintre ele pot apărea în mod excepțional, ca semn al autorităţii sau ca instrument persuasiv în rîndul anumitor categorii de emițători. Pentru epistolier, o importanță semnificativă dobîndește protocolul final. Un element definitoriu îl reprezintă urarea finală, notată după expoziție, care, în funcție de contextul redactării, poate lipsi sau poate deveni un adevărat exemplu de solemnitate și reverențiozitate. Data fixează timpul și locul redactării și, atunci cînd apare, este plasată după urarea finală. Documentele păstrate din secolele al XVI-lea și al XVII-lea se încheie prin unul sau mai multe semne de validare, iar în scrisori cel mai frecvent este întrebuințată pecetea.

Sf. Augustin are meritul de a fi adaptat doctrina celor trei ipostaze ale elocuției-stilul simplu, stilul moderat și stilul înalt_la specificul oratoriei creștine (a se vedea Milică, 2015) și, implicit, la arta scrisului epistolar, prin analiza retorică a epistolelor pauline în conformitate cu preceptele clasice ale artei elocinței. Abia după un mileniu, adică începînd cu secolul al XV-lea, cărturarii renascentiști vor prelucra canonul celor trei stiluri ${ }^{1}$ în conformitate cu solicitările teoriei epistolare laice (Mack, 2011, p. 236). Nuanțarea se va fi petrecut pe fondul recunoașterii, încă din Antichitate, a stilului simplu, cu ornamentație austeră, ca mijloc compozițional fundamental în scrisul epistolar. Cercetările contemporane de retorică și stilistică valorifică în manieră implicită această moștenire, în manuale în care se recomandă diverse strategii de adecvare compozițională, aplicate în acord cu regimul corespondenței purtate (Bly, 2004) și în lucrări teoretice în care se dezbate existența a trei variante stilistice ale epistolarității: familiară, oficială și solemnă (Irimia, 1999, p. 159; Dumistrăcel, 2007, p. 74-77).

În scrierile lui Cicero, autorul cel mai citit, comentat şi imitat de retorii medievali şi renascentiști occidentali, sistemul celor trei stiluri este corelat cu scopurile principale urmărite de orator (Cicero, 1973, p. 336-337), iar în Retorica ad Herennium (1964, p. 253), un vechi tratat de retorică intens valorificat în Renaștere, doctrina celor trei stiluri este lămurită succint ${ }^{2}$.

\footnotetext{
${ }^{1}$ Unii exegeți îi atribuie lui Teofrast, discipolul lui Aristotel, paternitatea sistemului celor trei stiluri, stilul simplu (umil), stilul moderat (comun, mijlociu, temperat) și stilul înalt (sublim, solemn, grav).

${ }^{2}$ „Există, așadar, trei feluri de stil, numite genuri, de care aparține orice discurs dacă e realizat fără greș: pe primul îl numim grav, pe al doilea, mijlociu, iar pe al treilea simplu. Stilul grav constă în aranjarea armonioasă și împodobită a cuvintelor alese.
} 
Cicero consemnează cu meticulozitate atributele fiecărei ipostaze elocuţionale. Oratorul care adoptă stilul simplu vorbește în cuvinte pe înțelesul tuturor și cu modestie, în așa fel încît, în aparență, să nu se deosebească de cei ce nu stăpînesc arta de a cuvînta. Funcția acestui stil este de a informa și de a educa auditoriul. De aceea, efectele retorice se cuvin realizate mai mult prin idee decît prin expresie, astfel că „cei care-l ascultă [pe orator - n.r.], deși sînt ei înșiși incapabili să vorbească, au totuşi convingerea că în felul acesta ar putea vorbi și ei” (Cicero, 1973, p. 339). Construcția și execuţia discursivă trebuie să redea dezideratul simplității. Din cuvîntare va fi îndepărtat orice ornament stilistic ostentativ, limba, deși uzuală, se folosește corect, exprimarea este clară și exactă, iar grija pentru ceea ce e potrivit răzbate limpede din discurs. Stilul simplu constă în formularea de cugetări pătrunzătoare, originale și profunde, înveșmîntate într-o limbă corectă, dominată de acuratețe, claritate și prudență ornamentală.

În convergență cu astfel de precepte, autorii de tratate epistolare consideră că stilul simplu se potrivește cel mai bine scrisorilor care aparțin registrului familiar. În practica epistolară din spațiul cultural românesc $^{3}$ această organizare compoziţională caracterizează, cel mai adesea, scrisorile de familie (Tabela 2):

Tabela 2: Exemple de texte epistolare compuse în stil simplu

\begin{tabular}{|c|c|c|c|c|}
\hline & & Mărica Mătiiasa & Cocrișel & Ștefan Brîncoveanu \\
\hline \multirow{4}{*}{$\begin{array}{l}\text { Protocolul } \\
\text { inițial }\end{array}$} & $\begin{array}{l}\text { invocația } \\
\text { simbolică }\end{array}$ & & $t$ & \\
\hline & intitulația & $\begin{array}{l}\text { Eu, Mărica Mătiiasa din } \\
\text { tara Moldovei, din satul } \\
\text { din Stăjăreni }\end{array}$ & & \\
\hline & adresa & $\begin{array}{l}\text { (scriu) la tine, bărbate } \\
\text { Mătei, carele șezi în Țara } \\
\text { Ungurească }\end{array}$ & $\begin{array}{l}\text { părinteloi meu }<\text { Spi>ridon și } \\
\text { maiciei méle Costandeei }\end{array}$ & Cinstită dumneata mamă \\
\hline & salutația & & $\begin{array}{l}\text { Scriu închinăciune și moltă } \\
\text { sănătate }\end{array}$ & $\begin{array}{l}\text { cu plecăčcune sărut cinstită } \\
\text { măna dumitale și rog pre } \\
\text { puternicul Dumnezeu să } \\
\text { dăruiască dumitale fericită } \\
\text { sănătate înpreună cu tot binele }\end{array}$ \\
\hline \multirow[t]{3}{*}{ Contextul } & notificația & dau-țiștire & Și dup-acéia vă dau știre & $\begin{array}{l}\text { Pricina scrisorii mele către } \\
\text { dumneata de astă dată de alt } \\
\text { nu ieste făr numai, întăi, să } \\
\text { aflu de buna și mie mult } \\
\text { veselitoare sănătate } \\
\text { dumneavostră; a doao ca să } \\
\text { aduc dumitale bună vestire etc. }\end{array}$ \\
\hline & expoziția & $\begin{array}{l}\text { cum eu-s beteagă și, de } \\
\text { casă, nu-s de a ținè; că eu } \\
\text { am bolnăvit; Iar eu mă } \\
\text { voiu ține aicea, în } \\
\text { Moldova, lîngă oamenii } \\
\text { miei, pînă cînd voi custa; }\end{array}$ & $\begin{array}{l}\text { Deci mă rog domnilor vostre } \\
\text { ca lui Domnedză<u> den } \\
\text { ceriu să nefoiți <să }>\text { mă scoteți } \\
\text { lîngă voi în țară creștină (...) } \\
\text { că eu dzacu în timniță de mă } \\
\text { mănî<n>că liutul și } \\
\text { pă <du>chie; } \\
\text { Deci iară mă rog domnilor } \\
\text { vostre să no mă zăbăviț aici } \\
\text { (...) că iu mor de dorol vostru. } \\
\text { Și înbătrănesco, și am făcoto } \\
\text { barbă pînă în brîu. }\end{array}$ & $\begin{array}{l}\text { Numai ci’m gătiț toate căte o } \\
\text { basmà cu fir, c’apoi nu va fi } \\
\text { bine de voi. Lea[lei] } \\
\text { Stan[căi], lea[lei] Ilin [căi], } \\
\text { lea[lei] Săf[ticăi] le sărut } \\
\text { măinile și să le zič să fie gata } \\
\text { basmalele cînd voi veni; } \\
\text { Lealii Stancăi să-i spui cum că } \\
\text { pă neanea Radul îl dor } \\
\text { mäinile poțintel; }\end{array}$ \\
\hline & dispoziția & & & \\
\hline
\end{tabular}

Stilul mijlociu este alcătuit din cuvinte mai simple, deși nu din cele mai banale și mai uzuale. Stilul simplu ține de cuvintele cele mai folosite în vorbirea obișnuită” (Retorica ad Herennium, 1964, p. 253).

${ }^{3}$ În studiul de față, fragmentele de texte epistolare sînt preluate în special din colecțiile de documente Documenta Romanice Historica (DRH): Documenta Romanie Historica. A. Moldova, Editura Academiei Române, București, 1969-2006 (DRH A) și Documenta Romania Historica. B. Țara Românească, Editura Academiei Române, București, 1965-2006 (DRH B). 


\begin{tabular}{|c|c|c|c|c|}
\hline & $\begin{array}{c}\text { clauza } \\
\text { prohibitivă }\end{array}$ & & & \\
\hline & sancțiunea & & & \\
\hline & coroborația & & & \\
\hline \multirow[t]{3}{*}{$\begin{array}{l}\text { Protocolul } \\
\text { final }\end{array}$} & $\begin{array}{l}\text { urarea } \\
\text { finală }\end{array}$ & Şi să fii sănătos, amin. & $\begin{array}{l}\text { Si }<s>a ̆ \text { afle aiasta scrisore a } \\
\text { mea sănătos pre domeavostră, } \\
o G<o s p o d>i \text {, amin. }\end{array}$ & $\begin{array}{l}\text { Mila lui Dumnezău să } \\
\text { păzească pre dum. }\end{array}$ \\
\hline & data & $\begin{array}{l}\text { Şi am scris în sat } \\
\text { Stăjăreni, Iunie } 13 \text { zile }\end{array}$ & & Mai 27 dn., lt. 7211 \\
\hline & $\begin{array}{l}\text { semnele de } \\
\text { validare }\end{array}$ & & $\begin{array}{l}\text { t } F<e>\text { ciorol vostru Cocrişel; } \\
\text { și simtu nomai co că }<\text { sessa }>\text {. }\end{array}$ & $\begin{array}{l}\text { Al dum. de fii cei mici și } \\
\text { plecat. Şt. B.” }\end{array}$ \\
\hline
\end{tabular}

În viziunea lui Cicero, stilul moderat este caracterizat de eleganță și are funcția de a mișca auditoriul. Retorul afirmă că acestui tip discursiv i se potrivesc poboabele alese cu discreție și eleganță, deoarece elocuția e mai amplă și întrucîtva mai viguroasă decît în cazul stilului simplu, căci „e vorba de un gen de stil ales și înflorit, mai mult chiar, colorat și șlefuit cu grijă, în care se îmbină toate farmecele cuvîntului și ale gîndirii” (Cicero, 1973, p. 345). Pe terenul scrisului epistolar românesc, stilul moderat este mai cu seamă prezent în registrul oficial al corespondenței purtate de reprezentanții marii boierimi sau ai clerului înalt ori în epistolele emise din cancelaria domnească către aristocrați și clerul înalt (Tabela 3):

Tabela 3: Exemple de texte epistolare compuse în stil moderat

\begin{tabular}{|c|c|c|c|c|}
\hline & & Alexandru Coconul voievod & Mihai Viteazul & $\begin{array}{l}\text { Episcopul Serafim al } \\
\text { Buzăului }\end{array}$ \\
\hline \multirow[t]{4}{*}{$\begin{array}{l}\text { Protocolul } \\
\text { inițial }\end{array}$} & $\begin{array}{l}\text { invocația } \\
\text { simbolică }\end{array}$ & & $t$ & $t$ \\
\hline & intitulaţia & $\begin{array}{l}\text { Cu mila lui Dumnezeu, Io } \\
\text { Alexandru voevod și domn, } \\
\text { feciorul răposatului Io Radu } \\
\text { voevod. }\end{array}$ & & \\
\hline & adresa & $\begin{array}{l}\text { Scris-am domniia mea voăo } \\
\text { satul Marotinul }\end{array}$ & $\begin{array}{l}\text { Bane Mihalcio și tu, vistiiar } \\
\text { Stoico }\end{array}$ & $\begin{array}{l}\text { Prea milostive și prea } \\
\text { luminate doamne }\end{array}$ \\
\hline & salutaţia & & & $\begin{array}{l}\text { să fii măriia ta sănătos. } \\
\text { Milostivul Dumnezeu să-ți } \\
\text { dăruiască tot binele măriii } \\
\text { tale. }\end{array}$ \\
\hline \multirow{2}{*}{ Contextul } & notificația & $\begin{array}{l}\text { După aceia, vă dau în știre } \\
\text { domniia mea }\end{array}$ & dau-vă în știre & Alta fac în știre măriii tale \\
\hline & expoziția & $\begin{array}{l}\text { Adevăr domniia mea văz și } \\
\text { crez că ați avut păs și greu nu } \\
\text { numai voi, ci și toată țara. Şi } \\
\text { domniia mea încă am avut } \\
\text { destule grele (...) }\end{array}$ & $\begin{array}{l}\text { pentru omul cistitului } \\
\text { impărat, ce-au trimes la noi; } \\
\text { ce noi, cum au fost porunca } \\
\text { impăratului și cum au fost } \\
\text { scris în cărțile măriii lui la } \\
\text { noi, ce ne va fi pohta noi să } \\
\text { dăm în știre împărățiii lui de } \\
\text { toate; ce, într-aceaea noi, de } \\
\text { ce ne-au fost pohta am scris tot } \\
\text { intr-această carte ce am } \\
\text { trimes la domneavoastră.; } \\
\text { iar voi să căutaț pre această } \\
\text { pohtă ce-am pohtit noi.; } \\
\text { și, în vreamea ce veți tocmi }\end{array}$ & $\begin{array}{l}\text { că aici înaintea smereniei } \\
\text { noastre venit-au Radul } \\
\text { portarul cu răvașele măriii } \\
\text { tale; } \\
\text { Dereptu aceea, cum au jurat } \\
\text { ei și cum au mărturisit ei cu } \\
\text { sufletele lor înaintea smerenii } \\
\text { noastre și au luat și blăstem } \\
\text { cu ofurisanie după jurămîntul } \\
\text { lor, smereniia noastră încă fac } \\
\text { in știre măriii tale. Măriia ta } \\
\text { ești bun și milostiv, ci vei face } \\
\text { cum te va năstăvi milostivul } \\
\text { Dumnezeu. }\end{array}$ \\
\hline
\end{tabular}




\begin{tabular}{|c|c|c|c|c|}
\hline & & & $\begin{array}{l}\text { pre această tocmeală, voi cum } \\
\text { mai curînd, de olac, să-m } \\
\text { trimeateți om cu carte de olac, } \\
\text { să-m dațin știre domniii } \\
\text { meale. Şi am dat învățătură } \\
\text { și lui Pandazi logofăt ce vă va } \\
\text { spune și den gură, aceaea vă } \\
\text { dau în știre }\end{array}$ & \\
\hline & dispoziția & $\begin{array}{l}\text { Deci, de vreme ce veți vedea } \\
\text { această carte a domnii mele, } \\
\text { iar voi să căutați să vă } \\
\text { inturnați pre la casele voastre, } \\
\text { să vă apucați de plug și de } \\
\text { hrană, iar de către domniia } \\
\text { mea veți avea pace și răpaos } \\
\text { (...) Iar alt val sau bintuială } \\
\text { de către domniia mea nimica } \\
\text { nu veți mai avea de acuma } \\
\text { innainte. }\end{array}$ & & \\
\hline & $\begin{array}{c}\text { clauza } \\
\text { prohibitivă }\end{array}$ & $\begin{array}{l}\text { Intr-alt chip să nu fie, după } \\
\text { zisa domniiai mele. Şi însumi } \\
\text { am zis domniia mea. }\end{array}$ & & \\
\hline & sancțiunea & & & \\
\hline & coroborația & & & \\
\hline $\begin{array}{l}\text { Protocolul } \\
\text { final }\end{array}$ & $\begin{array}{l}\text { urarea } \\
\text { finală }\end{array}$ & & I $\widetilde{B} \check{u} v i v e(s) l i(t), \operatorname{ami}(n)$. & $\begin{array}{l}\text { Милость Божї̈ стово } \\
\text { и господства та }\end{array}$ \\
\hline & data & $\begin{array}{l}\text { Scris maiu } 5 \text { zile, vă leat } \\
7135<1627>\end{array}$ & $\operatorname{Pi}(s) g e(n) 26 d(n), 1600$ & \\
\hline & $\begin{array}{l}\text { semnele de } \\
\text { validare }\end{array}$ & & $\begin{array}{l}\text { Io Mihail vodă (autografă) - } \\
\text { pecete inelară de ceară roșie, } \\
\text { deteriorată, a lui Mihai } \\
\text { Viteazu }\end{array}$ & $\begin{array}{l}\text { Gмћремны епискшп } \\
\text { Gерафим Б8зевскїи }\end{array}$ \\
\hline
\end{tabular}

Stilul înalt este manifestarea elocvenței „care poate conduce sufletele cum vrea și le poate mișca puternic în toate chipurile" (Cicero, 1973, p. 345). În oratorie, acest tip de elocuţie este cel mai amplu, cel mai bogat, cel mai strălucitor. Oratorul care stăpînește simplitatea este abil și ingenios, un maestru al elocuţiei moderate este încrezător și temperat, însă desăvîrșirea pe care o presupune stilul înalt necesită vitalitate, agerime și înflăcărare. Elocuția sublimă captivează auditoriul, pătrunde în suflete, „,împlîntă acolo idei noi și le smulge din rădăcini pe cele vechi” (Cicero, 1973, p. 345). Varianta înaltă a stilului epistolar se reflectă în registrul solemn, protocolar, al scrisorilor schimbate între conducători și este valorificată rar în stilul epistolar românesc vechi (Tabela 4):

Tabela 4: Exemple de texte epistolare compuse în stil înalt

\begin{tabular}{|c|c|c|c|}
\hline & & Ludovic I, regele Ungariei & Constantin-Vodă Brîncoveanu \\
\hline \multirow[t]{3}{*}{$\begin{array}{l}\text { Protocolul } \\
\text { inițial }\end{array}$} & $\begin{array}{l}\text { invocația } \\
\text { simbolică }\end{array}$ & & $t$ \\
\hline & intitulația & $\begin{array}{l}\text { Ludovicus, dei gratia, Hungarie, Dalmatie, } \\
\text { Croatie, Rame, Servie, Gallicie, Lodomerie, } \\
\text { Cumanie, Bulagarieque rex, princeps } \\
\text { Salernitanus, et honoris Montis sancti } \\
\text { Angeli dominus }\end{array}$ & $\begin{array}{l}\text { + Io Constantin Voevod, cu mila lui } \\
\text { Dumnezeu Domn al Țerii-Românești }\end{array}$ \\
\hline & adresa & $\begin{array}{l}\text { omnibus Christi fidelibus, tam presentibus, } \\
\text { quam futuris, presentem paginam inspecturis }\end{array}$ & $\begin{array}{l}\text { † Cinstiților și ai noștri buni prieteni și } \\
\text { vecini de aproape, în toată vremea de bine } \\
\text { voitori, dumnealor tot cinstitul Sfat al } \\
\text { cinstitei cetăți Brașovul }\end{array}$ \\
\hline
\end{tabular}




\begin{tabular}{|c|c|c|c|}
\hline & salutația & salutem in omnium salvatore & $\begin{array}{l}\text { sănătate și tot binele poftim d-voastră de la } \\
\text { Dumnezeu. }\end{array}$ \\
\hline \multirow{6}{*}{ Contextul } & notificația & & \\
\hline & expoziția & $\begin{array}{l}\text { Regie sublimitatis honore primarumque } \\
\text { executione decoratur, ut attentionis sue } \\
\text { gratitudinis studio illic omnem reprimat, } \\
\text { aciem sue mentis, unde noverit celsitudinis } \\
\text { munus recepisse, tantoque in sua gloria } \\
\text { clarior permanet, quanto in divinis cultibus } \\
\text { et religiosorum considerationibus solertior } \\
\text { invenitur; } \\
\text { Nos itaque, instantissimis supplicationibus } \\
\text { eorundem fratrum cruciferorum nobis } \\
\text { porrectis inclinati advertentes, quod per tales } \\
\text { versutias hominum perversorum possessiones } \\
\text { dicti ordinis alienarentur ab eodem, } \\
\text { cupientes igitur eisdem fratribus per } \\
\text { oportuna subsidia succurrere in premissis etc. }\end{array}$ & $\begin{array}{l}\text { Cinstită cartea d-voastră, ce ați trimis, ni-au } \\
\text { venit, și, de a d-voastră întreagă sănătate } \\
\text { înțelegînd, bucuratu-ne-am și am dat laudă } \\
\text { lui Dumnezeu; } \\
\text { Dar ce să facem? Pentru multe păsuri și mari } \\
\text { cereri și grele porunci ce avem de la cei ce ne } \\
\text { stăpînesc, care unul Dumnezeu știe în ce greu } \\
\text { ne aflăm și cu cîtă dătorie s'au încărcat ceastă } \\
\text { biată țară; - pentru aceia s'au făcut socoteală } \\
\text { cu tot Sfatul boierimii țerii noastre (...) } \\
\text { Şi, după aceasta, dînd Dumnezeu să mai } \\
\text { răsuflăm, nu vor mai avea de aceste supărări, } \\
\text { nici aceștia de țara d-voastră, nici } \\
\text { pămîntenii noștri }\end{array}$ \\
\hline & dispoziția & & \\
\hline & $\begin{array}{c}\text { clauza } \\
\text { prohibitivă }\end{array}$ & & \\
\hline & sancțiunea & & \\
\hline & coroborația & $\begin{array}{l}\text { In cuius rei memoriam perpetuamque } \\
\text { firmitatem presentes concessimus nostras } \\
\text { literas privilegiales, pendentis et authentici } \\
\text { sigilli nostri dupplicis munimine roboratas. }\end{array}$ & \\
\hline \multirow[t]{3}{*}{$\begin{array}{l}\text { Protocolul } \\
\text { final }\end{array}$} & $\begin{array}{l}\text { urarea } \\
\text { finală }\end{array}$ & & $\begin{array}{l}\text { Şi cu aceasta sfîrșind, mila lui Dumnezeu să } \\
\text { fie cu d-voastră. }\end{array}$ \\
\hline & data & $\begin{array}{l}\text { Anno domini MCCCLVII, quarto Nonas } \\
\text { mensis Martis, regni autem nostri anno } \\
\text { sedecimo. }\end{array}$ & $\begin{array}{l}\text { Scris in Tirgoviște, Ghenarie 13, leatul } 7215 \\
\text { [1707] }\end{array}$ \\
\hline & $\begin{array}{l}\text { semnele de } \\
\text { validare }\end{array}$ & & $\begin{array}{l}\text { De bine voitor d-voastră Io Constandin } \\
\text { Voevod }\end{array}$ \\
\hline
\end{tabular}

Constatînd că cele trei variante stilistice fixate, în Renaștere, în tradiţia compoziţională a scrisorilor sînt prezente și în scrisul epistolar românesc, se cuvine adăugat că analiza retorică a unor texte epistolare redactate în limba română permite reliefarea unui inventar de proprietăți elocuţionale (trăsături stilistice) ale textelor epistolare.

Anticipam, în Milică \& Morcov (2016, Secțiunea 2), că, la finele secolului al XVI-lea, erudiți precum învățatul flamand Justus Lipsius includeau în tratatele de retorică epistolară considerații asupra caracteristicilor stilului epistolar (Figura 1): concizie (brevitas), claritate (perspicuitas), naturalețe (simplicitas), eleganță (venustas) și potrivire (decentia), înscriindu-se astfel în matca nobilei tradiții retorice asupra calităților și defectelor stilului (cf. Milică, 2014, p. 41-48).

Dezideratul conciziei subliniază recomandarea de a stabili un echilibru între importanța tematicii abordate în scrisoare și întinderea textului. Tematica simplă necesită o compoziție simplă și scurtă, în timp ce tematica complexă, precum cea dezvoltată în scrisorile erudite sau de înalt protocol, favorizează o desfășurare textuală considerabil mai întinsă.

Claritatea este proprietatea de a exprima cu rigoare idei bine reliefate. În textul epistolar, această trăsătură stilistică se concretizează în utilizarea corectă și rațională a resurselor de limbaj.

Naturalețea are în vedere exprimarea directă și sinceră a ideilor, fără ca textul scrisorii să fie ostentativ și pompos, prin uzul artificial și excesiv de ornamente expresive.

Eleganțta pune în valoare finețea de spirit a epistolierului și indică gradul de instrucție al acestuia. Ca marcă de identitate epistolară, această trăsătură compozițională este mai bine reliefată în stilul moderat și 


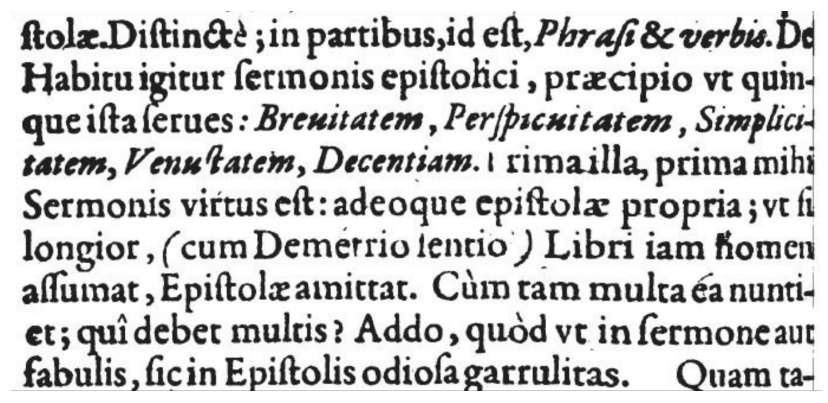

Figura 1: Fragment din tratatul de retorică epistolară al lui Justus Lipsius, Epistolica Institutio (1591).

înalt, din moment ce presupune ornarea scrierii cu proverbe, citate sau vorbe de duh.

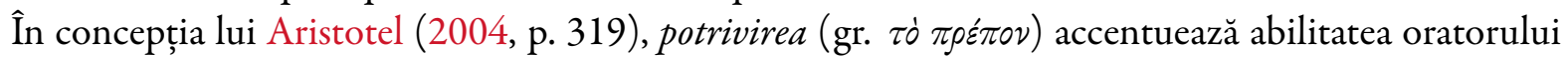
de a adapta discursul în acord cu propria dispoziție și personalite, în conformitate cu starea de spirit a auditoriului și în congruență cu subiectul discursiv ales. Așadar, în oratorie, ca și în scrisul epistolar, potrivirea oglindește echilibrele tensiunilor din interiorul raportului emițător-mesaj-destinatar.

Începînd cu secolul al XVII-lea, acest inventar explicit de calități ale stilului epistolar s-a naturalizat progresiv în mecanica compozițională a scrisorilor, astfel încît manualele de retorică epistolară din secolul al XIX-lea le recomandă ca uzanțe implicite, prin care se configurează o etică și un ceremonial de corespondență, după cum se observă, de pildă, în epistolarul publicat de Urzescu (1840).

\subsection{Clasificarea funcţională a textelor epistolare scrise în limba română în secolele al XVI-lea și al XVII-lea}

Particularitățile retorice ale scrisului epistolar românesc se cuvin apreciate și interpretate în acord cu libertățile și constrîngerile interne (de natură lingvistică) și externe (de factură extralingvistică) ce caracterizează practica epistolară de la o etapă istorică la alta. De aceea, tipologia textuală pe care o propunem pentru vechiul scris epistolar românesc nu este nici infailibilă, nici exhaustivă, ci are menirea de a semnala dominantele compoziționale și funcționale ale stilului epistolar românesc în stadiile sale de constituire și de maturizare. Cadrul teoretic fructificat în realizarea taxonomiei este constituit de modelul comunicativ elaborat de Jakobson (1964), sub influența unor lucrări de pionierat precum cele ale lui Karl Bühler (Bühler, 2011) și Nicolai Trubețkoi (Troubetzkoy, 1949).

Dezvoltat pentru a surprinde dimensiunile semiotice ale actului de comunicare verbală, adică dimensiunea subiectivă, reprezentată de axa emițător - mesaj - receptor, și dimensiunea obiectivă, reprezentată de axa context - cod (concretizat ca formă a mesajului) - canal, modelul jakobsonian a înlesnit clasificarea textelor epistolare în funcție de identitatea socio-culturală și de competența expresivă a emițătorului (emitentul), de apartenența socio-culturală și de atitudinea stilistică a receptorului (adresantul) și de conținutul mesajului epistolar în raport cu un anumit tip de context, cu un anumit cod lingvistic și cu specificul canalului de realizare a comunicării.

Din unghiul apartenenței socio-culturale a emitentului au fost identificate trei categorii dominante de texte epistolare: scrisori emise de domnitori, scrisori emise de clerul înalt și scrisori emise de diverse categorii de dregători. Din punctul de vedere al numărului de participanți la elaborarea și transmiterea scrisorii, am considerat utilă deosebirea între emitentul unic și emitentul colectiv. În realizarea opoziției masculin feminin, au prezentat interes scrisorile trimise de epistolieri de sex masculin și scrisorile puse in circulație de epistolieri de sex feminin.

În simetrie cu focalizarea asupra emitentului, focalizarea asupra statutului socio-cultural al adresantului ne-a permis să distingem între scrisorile adresate domnitorilor, scrisorile către reprezentanții de frunte ai Bisericii și scrisorile adresate dregătorilor importanți în economia scrisului epistolar al vremii. Inițiativa redactării a constituit criteriul de indicare a unor trăsături ale scrisorilor inițiale, în raport cu scrisorile de răspuns și cu scrisorile de intervenție.

Întemeiat pe opoziția public - privat, studiul solidarității semiotice între mesaj și context (referent) a favorizat gruparea textelor epistolare în două categorii, a) corespondența oficială, dominată de corespondența 
Gabriela-Iuliana Morcov, Ioan Milică

legală (administrativ-juridică), corespondența diplomatică și corespondența comercială, și b) corespondența privată, mai slab reprezentată și în interiorul căreia e, în lumina documentelor cunoscute, dificil de realizat distincții structural-funcționale.

Luarea în considerare a codului și a canalului de desfășurare a comunicării epistolare a îngăduit formularea unor comentarii asupra ceremonialului de comunicare epistolară în epoca veche a scrisului în limba română.

\subsubsection{Emitentul}

În epoca veche a scrisului literar românesc, la polul emitentului, ritualul comunicării epistolare e în genere guvernat de spiritul de conservare în utilizarea formulelor specifice textului epistolar, pe fondul tensiunilor dintre imitarea cvasi-mecanică a cutumelor fixate prin tradiția utilizării unor modele străine și imitarea relativ creatoare a acestor modele.

\subsubsection{Scrisori emise de domnitori}

În chip firesc, istoria stilului epistolar românesc începe în cancelariile domnești. Sub influența culturilor epistolare de limbă latină şi slavonă, scrisul epistolar se concretizează în prima codificare retorică menită să îi asigure funcționalitatea, iar scrisorile de domni din secolele al XVI-lea şi al XVII-lea adoptă frecvent formularul schematizat în Tabela 1. Cu puține excepții, epistolele debutează prin invocarea simbolică a divinităţii, reprezentată prin semnul crucii, în spiritul unei epoci în care se întrevede credința omului medieval că orice demers este ghidat de autoritatea divină. Prima notă distinctivă este imprimată scrisorilor domnești prin intitulație, element structural indispensabil, emblemă a autorității cu care este învestit emiţătorul. Introdusă în debutul fiecărui document, această formulă fixă ilustrează gradul maxim de convenționalizare a formularului epistolar întrebuințat în epocă. Formulele tipice respectă următorul tipar: „Noi, Vasilie v(oie)vod, cu mila lui Dumnezău, domnu Țărăi Moldovii” (DRH A, XXIV/122), iar uneori pot cuprinde și filiația: „Cu mila lui Dumnezeu, Io Alexandru Voevod și domn, feciorul răposatului Io Radu voevod" (DRH B, XXI/224), componentă care va fi preluată și de emitenți aparținînd altor categorii socio-culturale de epistolieri. Foarte frecvente sînt, însă, cazurile în care identitatea emitentului este redată prin șabloane în limba slavonă, deși documentul este redactat în limba română: „† Иw Васипїє воєв॰аa,

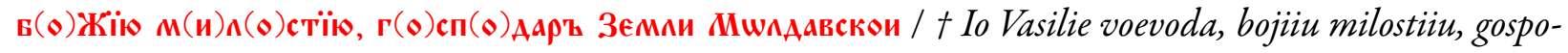
dar Zemli Moldavscoi" (DRH A, XXIII/194).

Adresa sau inscripția este o componentă vitală a scrisorii, nelipsită nici din epistolele domnești, unde este introdusă adesea prin structura „scrie $(m)$ domnia mea”. Atunci cînd apartenența socio-culturală a destinatarului o cere, adresa este construită reverențios, de obicei în limba slavonă, înscriindu-se în ace-

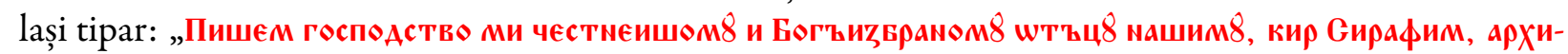
єпискөп Б8zовски.” („Scrie domnia mea cinstitului și de Dumnezeu ales părintelui nostru, chir Serafim, arhiepiscop Buzăului”, DRH B, XXXVII/309). Deși este unul din elementele care diferențiază scrisoarea de alte tipuri de documente, salutația este foarte rar întîlnită în scrisorile redactate de domnii veacurilor al XVI-lea și al XVII-lea, iar atunci cînd apare, în corespondența cu vreun reprezentant al Bisericii (DRH B, XXXVII/309), cu vreun boier (DRH B, XXXVII/306) sau cu vreo ,jupîneasă” (DRH B, XXXIV/247), se rezumă la formula simplă „sănătate” sau la corespondentul acesteia în limba slavonă, „ЂАравNe”.

La nivelul contextului, scrisorile prezintă și componente nespecifice scrisului epistolar, ci altor categorii de documente. De pildă, multe epistole domnești conțin o dispoziție, în special în cazul corespondențelor cu boieri, obști mănăstirești, dregători sau alți destinatari cu atribuții administrative. Aceasta este anunțată de structuri precum „Pentr-acea, dacă vei vedea cartea domniei méle” (DRH A, XXVIII/162), „Deci, de vreme ce veți vedea această carte a domnii mele” (DRH B, XXI/224) și se încheie prin enunțuri imperative, reprezentînd așa-numitele clauze prohibitive: „Aceasta-ț grăiescu domnia mea și într-alt chip să nu faci." (DRH B, XXXIV/247).

Un interes deosebit prezintă scrisorile, reduse ca număr, în care clauzelor prohibitive li se adaugă sancțiunea, al cărei conținut variază de la simpla certare domnească: „bini să știi că mari certare ver avea di 
cătră domnia mea” (DRH B, XXXV/131), la fragmente discursive cu accentuată forță persuasivă: „,bine să știți că voiu să tremiț domnia mea om domnescu să vă spargă casele fără de voia voastră. Să nu văpae întraltu chip!" (DRH B, XXXVI/25).

Şi în privinţa protocolului final scrisorile de domni se disting prin faptul că, în general, urarea finală lipsește, excepțiile fiind determinate de corespondența cu destinatari care dețin același statut social sau de comunicarea cu înalte fețe bisericești. Protocolul final este elaborat de cele mai multe ori în limba slavonă, conținutul acestuia adoptînd de obicei următorul model: "La Iași, în anul 7142 <1633> sept<embrie> 16.1 + Domnul a spus./ + Ghianghea mare log<ofăt> a învățat./ † Tănasie a scris" (DRH A, XXI/399).

\subsubsection{Scrisori emise de clerul înalt}

Clerul înalt este alcătuit din patriarhi, mitropoliți și episcopi a căror activitate epistolară constă în emiterea unor cărți de blestem sau de adeverire ori a unor acte de întărire sau cu alt rol. Și în cazul acestor scrisori, convenționalizarea formularistică este maximă și pune în lumină specializarea comunicativă orientată de statutul socio-cultural al adresantului.

Deși se construiește în jurul unui nucleu ce indică numele, rangul și locul de păstorire, intitulația este diferită pentru patriarh: „† Chiril cu mila lui Domnezeu arbiepiscop cetăție lui Constantin, Rîmului Nou și

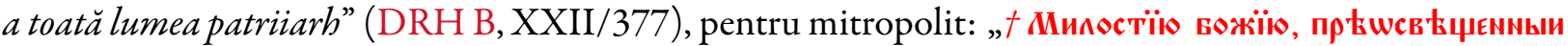
күр Грїгорї, митрополит въсои земли Влашкои. / + Cu mila lui Dumnezeu, Preasfințitul chir Grigorie mitropolit a toată Țara Ungrovlabiei.” (DRH B, XXIII/53) și pentru episcop: „t Smeritul episcop Serafim al Buzăului" ${ }^{4}$. O altă componentă esențială, salutația, devine spațiul discursiv în care emițătorul își asumă rolul de mesager al cuvîntului divin: „dar vooa șipace și milă de la Domnezeu a tuturor țiitori și de la domnu nostru Iisus Hristos" (DRH B, XXII/377).

Fiind în general motivată de solicitarea unei persoane sau a unui grup de persoane care aleg să ị̂si gestioneze conflictele ori să își apere proprietățile prin apelul la autoritatea înalților ierarhi, majoritatea scrisorilor îmbracă forma „cărților de afurisenie”, iar orientarea către destinatar e amplificată în partea finală a conținutului, unde clauza prohibitivă și sancțiunea spirituală, rareori dublată de cea materială, generează un cadru de maximă intensitate discursivă. Așadar, scrisorile emise de prelați își cristalizează structura și formulele specifice prin raportare la modelul retoric de tip slavon, dar și sub influența modelului epistolelor biblice, înscriindu-se, astfel, într-o tradiție îndelungată care asigură acestei categorii de scrisori cel mai înalt grad de stabilitate retorică.

\subsubsection{Scrisori emise de diverse categorii de dregători}

Membrii cancelariei domnești sau alți emitenți cu funcții administrative (mari dregători, logofeți, vornici, boieri cu rang etc.), au intensificat obiceiul corespondenței, iar prin rolul frecvent de intermediar între domn și popor au potențat familiarizarea oamenilor simpli cu formularistica epistolară a vremii. Aceste mesaje cu caracter oficial nu se abat de la normele de redactare cunoscute și se disting în special la nivelul acelor formule inițiale și finale prin care emițătorul stabilește raportul cu receptorul și gradul de formalitate sau, acolo unde este cazul, gradul de reverențiozitate. Atît în corespondența cu domnii țării, cît și în scrisorile către destinatari aparținînd unor categorii sociale de rang inferior, ceremonialul epistolar se înscrie în liniile formalității, însă mărcile acesteia sînt diferite, opțiunile fiind motivate, pe de o parte, de autoritatea receptorului și, pe de altă parte, de poziția de putere și decizie a emitentului. Din epistolele către domni, de exemplu, nu pot lipsi adresa/inscripția: „Prea milostive doamne”, salutaţia: „Să fii măria ta/dumitale sănătos" și urarea finală. În scrisorile către destinatari de rang inferior, importantă devine intitulația care, introdusă uneori chiar prin structuri în limba slavonă: „GTo as” („adică eu”) și completată de filiaţie, are ca efect accentuarea distanței sociale dintre emițător și receptor: „t Eu Chisar păharnicul, feciorul Chircăi comisul de in Ruda (scris-am la voi satul Groşani)" (DRH B, XXV/347).

\footnotetext{
${ }^{4}$ În această epistolă, intitulația lipsește, rolul ei fiind suplinit de semnătura finală care indică numele, rangul eclezial și locul de păstorire al emitentului: „t Smeritul episcop Serafim al Buzăului”. Cu trecerea timpului, această permutare asociată adresei în vocativ se va regăsi din ce în ce mai des în structura textului epistolar.
} 
Interesant se prezintă schimbul epistolar între interlocutori cu aceeași apartenență socio-culturală, pentru că, deși funcționează în cadrele corespondenței oficiale, scrisorile adoptă strategii de apropiere, specifice politeții pozitive, nu negative. Dacă luăm ca exemple unele scrisori de solicitare sau de intervenție, adică documente cu caracter administrativ, observăm maniera în care adresa amplifică forța persuasivă: „la ai miei cinstiţi și preaiubiți și dulci și dragi părinți mai mari jupînul Lucaci marele bulgăr și la județul cel mare” (DRH B, XI/355). Tendința de diminuare a formalității ceremonialului discursiv și a distanței retorice dintre interlocutori se continuă prin elemente precum salutația sau urarea finală. Se observă, așadar, că ele dezvoltă, pe lîngă rolul fatic, dominant, și un rol expresiv.

\subsubsection{Numărul emitenților}

În prezent, ipostaza tipică a scrisorii este cea de punte de legătură între un emitent unic și un destinatar unic. Deși este un instrument firesc în corespondența cu caracter oficial, acest tip de scrisoare aparține prin excelență mediului privat, ideal pentru comunicarea spontană, autentică și cu un accentuat caracter intim. În corespondența oficială românească din secolul al XVII-lea sînt deosebit de frecvente situațiile în care cărțile au emitent colectiv, mai ales cînd raportul social stabilit între interlocutori este cel de inferioritate superioritate: „† Ci<n>stit și de Dumnedzău dăruitpărintele nostru, Pătrașco logofătul cel mare, multă viiață și sănătate ca să aibi dumneata de la domnul Dumnedzău, ce-au fácut ceriul și pămîntul și de la preacurata maică și ca să primești dumneata multă închinăciune de la mai mici feciorii dumitale, de la popa Ion den Read și de la Cămîrzan de acolea" (DRH A, XXII/176).

Pe fondul unui nivel foarte scăzut de instrucție, mica boierime, preoțimea de rînd sau țăranii simpli se adresau marilor dregători, boierilor și chiar domnului prin mijlocirea unui cunoscător al cutumelor scrisului epistolar, fie pentru a comunica îndeplinirea unor dispoziții, fie pentru a transmite solicitări de ordin administrativ-juridic. La rîndul lor, reprezentanții claselor conducătoare se conformau aceluiași ceremonial epistolar dacă erau ignoranți în privința cutumelor de întocmire a scrisorilor. Această stare de fapt semnalează că în vechiul scris epistolar era funcțională distincția de rol (Chițimia \& Toma, 1984, p. 31; Murphy, 2001, p. 204) între dictatores (cei ce compuneau diversele înscrisuri) și scriptores (cei însărcinați cu redactarea acestora).

\subsubsection{Scrisori de bărbați, scrisori de femei}

O altă distincție ce merită amintită este cea dintre emitentul de sex masculin și cel de sex feminin. În perioada veche a scrisului epistolar, redactarea scrisorilor se înscrie între activităţile desfășurate de bărbaţi și, prin excelență, de reprezentanți ai Bisericii sau ai puterii legislative. Considerabil mai reduse ca număr, scrisorile cu emitent feminin au existat, totuși, din zorii conturării stilului epistolar românesc. Avînd ca suport volumul Scrisori de femei alcătuit de Nicolae Iorga, vom observa că, dacă în plan formal, documentele tind să se conformeze aceluiaşi cod retoric utilizat de epistolierul oficial și acceptat ca normă a vremii, în planul conținutului astfel de scrieri se disting uneori prin problematica abordată, prin maniera de relatare, prin încărcătura afectivă a mesajului etc. Scrisorile respectă succesiunea convențională a secvențelor discursive, iar dintre elementele componente ale formularului epistolar se remarcă intitulația care de multe ori reflectă nevoia de validare a propriei identităţi, prin raportarea constantă la personalitățile masculine din cadrul familiei, motiv pentru care ea cuprinde și filiația sau relația de alianță: „Ileana Vorniceasa a răposatului Toader Cantacuzino biv Vel Vornic” (Iorga, 2011, p. 57).

\subsubsection{Destinatarul}

În concordanță cu ierarhizarea ce caracterizează profilul stilistic al scrisorilor clasificate în acord cu statutul emițătorului, în scrisul epistolar românesc se oglindește și o ierarhizare condiționată de identitatea destinatarului.

\subsubsection{Scrisori adresate domnitorilor}

În epoca veche, corespondența cu un conducător politic era guvernată de respectarea unui protocol discursiv caracterizat de reverențiozitate și noblețe. De obicei, formulele întrebuințate sînt convenționale și 
individualizează această categorie de scrisori la nivelul acelor secvențe structurale (adresa, salutația, urarea finală) în care funcțiile fatică și conativă domină asupra celorlalte funcții ale actului de comunicare verbală. Adresa se constituie din sintagme precum „Preamilostive doamne” sau „Milostive și luminate doamne”, salutația rămîne constantă de la o epistolă la alta, indiferent de statutul emitentului: „Să fii măriia ta/dumitale sănătos”, iar urarea finală desăvîrșește convenția de reverență din aceste epistole: „Dumnezeu să te veselească și să te zilească în ai mulți și buni, amin" (DRH B, XXIV/269).

\subsubsection{Scrisori adresate clerului inalt}

Emitentul conștientizează autoritatea deopotrivă spirituală și administrativ-juridică a destinatarului, astfel încît strategiile adresării devin esențiale în buna întocmire a scrisorilor către clerul înalt. În funcție de rangul destinatarului, de poziția ierarhică și de condiția culturală a emițătorului și de natura documentului, adresa, salutația și urarea finală sînt construite diferit, aceste secvențe fiind nelipsite într-un context în care atenția emițătorului este focalizată deopotrivă spre destinatar și spre referent. Chiar atunci cînd emitentul scrisorii este însuși domnul țării, se poate observa elaborarea atentă a protocolului iniţial, adaptat contex-

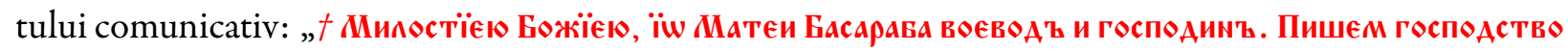
ми честнеишом8 и Бөгъизвраном8 штъц8 машим8, кир Сирафим, арХиепископ Б8зовски, заравме. / Din mila lui Dumnezeu, Io Matei Basarab, voievod și domn. Scrie domnia mea cinstitului și de Dumnezeu ales părintelui nostru, chir Serafim, arhiepiscop al Buzăului, sănătate.", dar și opțiunea pentru o formulă de adresare solemnă, ,sfinția ta", valorificată pe tot parcursul epistolei (DRH B, XXXVII/ 309).

\subsubsection{Scrisori adresate dregătorilor}

Atunci cînd domnul țării se adresează marilor săi dregători, salutația și urarea finală sint omise, iar adresa este păstrată ca element menit să asigure identitatea şi funcționalitatea documentului. Cînd emitenții sînt țărani liberi, obști sătești, reprezentanți ai micii boierimi sau membri ai cinului monahal, scrisorile reflectă un pronunțat caracter ierarhic, de asumată inferioritate și/sau modestie din partea emitentului. În astfel de documente, salutația și adresa, construite foarte reverențios, pot favoriza supralicitarea superiorităţii destinatarului: „t Cinstite al nostru părinte, dumneata giupîne Toderaşco, logofăt mare, să fii dumneata sănătos" (DRH A, XXVIII/70), în timp ce semnătura finală evidențiază toposul retoric al modestiei, subliniindu-se astfel distanța retorică și socială dintre protagoniștii comunicării epistolare: „t Mai mic fecior și sluga dumitale" (DRH A, XXVIII/70).

\subsubsection{Numărul destinatarilor}

În epoca veche, spectrul scrisorilor cu destinatar unic este completat de gama scrisorilor cu destinatar colectiv. Cele din urmă prezintă un interes aparte, ilustrînd de obicei înscrierea într-un raport social de superioritate - inferioritate. Comunicarea unor dispoziții, în mod direct sau prin intermediul unor scrisori de intervenție, reprezintă de multe ori obiectul acestui tip de comunicare, cînd adresa este construită simplu, fără a se insista asupra individualităţii receptorului: „Scris-am la voi satul Groşani” (DRH B, $\mathrm{XXV} / 347)$.

\subsubsection{Inițiativa redactării}

Un criteriu important de structurare a mesajelor epistolare, indiferent de destinația lor, publică sau privată, îl constituie inițiativa redactăriii ${ }^{5}$, parametru ce face posibilă clasificarea scrisorilor ca:

a) scrisori inițiale: sînt cele mai frecvente în practica epistolară publică și privată, emițătorul fiind agentul care declanșează interacțiunea textuală;

b) scrisori de răspuns: reflectă modul de raportare a destinatarului la mesajul emitentului. Destinatarul scrisorii inițiale își asumă acum rolul de emițător, elaborîndu-și discursul ca reacție la scrisoareastimul. Dacă ne îndreptăm atenția asupra unor vechi epistole românești, observăm că ele se disting prin formulări tipice introduse, în general, după adresă, înaintea expoziției, dar și prin alte elemente care

${ }^{5}$ În funcție de inițiativa trimiterii scrisorii, Vârgolici (2009, p. 67-69) distinge în cadrul corespondenței actuale între scrisori inițiale, scrisori de răspuns și scrisori de revenire. 
asigură continuitatea de context. Un exemplu în acest sens îl reprezintă o scrisoare din 1635, trimisă de voievodul Vasile Lupu boierului Racoviță, document în care aceste structuri specifice apar imediat după adresă: „Scriem Domniia Mea (...) de carte ce ai trimis la Domniia Mea. Ințeles-am scrisorei dumitale...”. În continuare, textul se raportează la mesajul primit și este construit ca un răspuns detaliat a cărui coerență este subliniată prin conectori: „Scrii dumneata cum (...)”, „Alta, te pohtești dumneata săfii (...)" (DRH A, XXIII/194).

c) scrisori de intervenție: pot fi eventual considerate variante ale scrisorilor inițiale, însă identitatea lor structurală și funcțională constă în faptul că emitentul își asumă rol de intermediar între emitent / receptor și o terță persoană, neimplicată direct în actul de comunicare. Cărțile de intervenție sînt foarte frecvente în activitatea de cancelarie din epoca veche, cînd diferite persoane cu funcții administrative îndeplineau roluri de intermediari, între domn și popor, pe de o parte, și, pe de altă parte, între părți implicate într-o cauză problematică sau conflictuală. Iată un fragment ilustrativ: „Scriem la priiatinul nostru, la Furtuna ce au fost comis. Dămu-ți știre pentru rândul cestui fecior al nostru, anume Nașcul de Moșetești, cum au <v>init de s-au jeluit pre dumneata, cu mare jalobă (...) Pentr-acela lucru, dăm știre, deacă vei vedea cartea noastră, iar dumneata să-l lași foarte in pace" (DRH A, XXV/413).

\subsubsection{Contextul și mesajul}

Tipologia textelor epistolare se organizează cu necesitate în conformitate cu opoziția public - privat. Dat fiind că scrisoarea este un text care exprimă viziunea epistolierului asupra diverselor stări de lucruri și întîmplări, mesajul transmis poate fi interpretat ca mediu semiotic de legătură între emițător, realitate și receptor, iar deosebirile de formă și de conținut dintre corespondența publică (oficială) și cea particulară (fie protocolară, fie familiară) luminează funcția referențială și condiția retorică a scrisului epistolar.

Regulile de întocmire a actelor emise de cancelariile domnești au determinat o standardizare a formularisticii documentelor medievale românești, calchiată după model slav (Chițimia \& Toma, 1984, p. 30), iar asemănările structurale ale protocoalelor inițial și final sau ale elementelor compoziționale ale contextului fac dificilă, în stadiul de început al scrisului epistolar, deosebirea scrisorilor de alte tipuri de acte. În această etapă, o clasificare comună surprinde trei categorii principale de documente (Chițimia \& Toma, 1984, p. 30): acte (privilegii domnești, angajamente între două persoane sau scrisori domnești care au un temei juridic), scrisori (corespondența de orice natură, adesea nelegată de scopuri juridice) și scripture (însemnări scurte sau documente conținînd anumite note și ciorne după care urmau să se redacteze apoi acte, petiţii, rapoarte).

Volumele seriilor din colecția DRH ne permit să observăm că pentru noțiuni precum 'act' sau 'scrisoare' se utilizează o nomenclatură ce ilustrează adeseori suprapuneri semantice. Faptul nu trebuie să surprindă, în condițiile în care, în tiparele scrisului din era bizantină, scrisoarea nu avea statut independent și complet distinct față de alte texte: omilii, scrieri teologice, istorice sau literare, uneori elaborate în stil epistolar (Jeffreys \& Kazhdan, 2000, p. 719), derivat, probabil, din imitarea modelului sacru al epistolelor pauline. În formularistica românească, încă neexplorată sistematic pentru a verifica dacă se respectă granița medievală între ars dictaminis şi ars notarie, adică între textele epistolare și cele legale, scrisoarea este denumită și carte, termen generic care apare și în titulatura unor documente cu valoare juridică: carte domnească, de judecată, de mărturie, de proprietate, de schimb, de afurisenie, de iertare etc.

În interiorul corespondenței oficiale, scrisorile se grupează în următoarele categorii:

a) Corespondența administrativ-juridică, care domină, în epoca de început, textele redactate în stil epistolar. De altfel, majoritatea epistolelor cu caracter administrativ și juridic sînt, în secolele al XVI-lea și al XVII-lea, emise de autoritatea domnească, de divanul marilor dregători, de marele vornic, de județul orașului sau de clerul înalt. Pot fi amintite aici numeroasele epistole ce conțin dispoziții domnești, precum cea emisă de Vasile Lupu, redată fragmentar în continuare: „Scriem domnia mea la slugile domniei mele, la aprodzi și la slugi hătmăneşti (...), Deaca veți vedea cartea domnii mele, iar voi să avețt a lă<sa> in pace țîgani svetii Ipiscopii de Roman (...). Aceasta vă scriem, mai multu val să nu le faceț." (DRH A, XXII/152). 
b) Corespondența diplomatică. Diplomația este în general definită drept activitatea, știința sau arta de a gestiona relațiile dintre state. Scrisoarea diplomatică, privată de avantajele elementelor non-verbale, își dovedește eficiența prin conţinutul convingător, prin valori retorice și prin respectarea în scris a unui protocol comunicativ, expresie a capacității creatorului de mesaj de a-și adecva discursul la situația istorico-politică cu care se confruntă și pe care o supune negocierii. Principiile comunicării diplomatice se manifestă în scrisul epistolar și în perioada veche a culturii române, mai ales în interacțiunile dintre conducătorii politici. Într-o scrisoare din 1599, adresată de Mihai Viteazul lui Ieremia Movilă (DRH B, XI/353), adresa, deși păstrează caracterul solemn specific comunicării diplomatice, poartă amprenta afectivității și subiectivismului „Scriem fratelui nostru din inimă celui mai iubit, Ioan Ieremia Moghilă voievod, din mila lui Dumnezeu, domn al țării Moldovei”. Respectînd rigorile etichetei protocolare, formula de salut „Urăm domniei sale lungă domnie și sănătate și fericire întru toate” reflectă tonul elegant păstrat pe parcursul întregii epistole. Urarea finală, „Cu aceasta dorim domniei tale de la domnul Dumnezeu sănătate și domnie fericită întru mulți ani”, se apropie prin semnificații de formularul celorlalte epistole adresate domnilor, amplificînd solemnitatea mesajului.

c) Corespondența comercială oferă coordonatele necesare pentru a înțelege modul în care textul ia naștere pornind de la o realitate extralingvistică ce, desfășurată în mod ritualic vreme îndelungată, duce la fixarea unor structuri, mai întîi în plan cognitiv și apoi la nivel comunicativ. Astfel, schematizările cognitive asociate oricărei acțiuni de schimb au generat texte specifice formalizate (cf. Metzeltin \& Thir, 2013). Foarte multe dintre documentele din perioada veche au valoarea actelor de proprietate asociate acțiunii de vînzare, cumpărare sau donație, însă mai puțin numeroase sînt scrisorile, corespondenţa directă între două persoane implicate într-un demers comercial care să aibă, în termeni actuali, caracter de cerere sau ofertă. Într-o astfel de epistolă, Ivașco, fost mare vornic, scrie lui Mușat: „pentru cea delniță ce-ai cumpărat de la Stănești (...), să o lași dumneata să fie pre séama noastră și ți-o voiu prinde in séama celor 18 galbeni" (DRH B, XXIII/360).

Spre deosebire de corespondența oficială, divizată în categorii relativ bine delimitate, o taxonomie a scrisorilor private este, în epoca de început a scrisului epistolar românesc, complicat de realizat, pentru că ar trebui să se constituie într-o analiză a rolurilor asumate de epistolieri. Născută din ritualurile comunicative animate de resort confesiv, scrisoarea personală, avînd caracter intim și afectiv, reflectă personalitatea unică a epistolierului, fiind îndeobște creditată ca exemplu de naturalețe și spontaneitate. Scrisorile particulare se caracterizează în general prin eliberare de convenții stilistice, devenind suporturi ale unor forme, structuri și opțiuni de expresie specifice limbii vii. În epoca veche, ele păstrează totuși convențiile stilului epistolar prin obişnuitele formule de început și de final, însă creativitatea emiţătorului are și aici un rol fundamental, putîndu-se manifesta prin abateri, omiteri sau inovații stilistice. Una dintre cele mai cunoscute și mai ilustrative scrisori de familie, datată în preajma anului 1600, este scrisoarea lui Cocrişel (DRH B, XI/419) care, luat prizonier în război, le scrie părinților despre condiția sa și despre încercările de a-şi redobîndi libertatea. În planul conținutului este evidentă expresivitatea emițătorului şi tonul familiar care dirijează organizarea textului epistolar. În ceea ce privește aspectul formal, se observă recursul la standardul de redactare al vremii. Protocolul inițial se rezumă la un singur enunț, care concentrează însă elementele definitorii: invocația simbolică, salutația și adresa: „t Scriu închinăciune și moltă sănătate părinteloi meu Spiridon și maiciei mele Costandeei”. Informaţiile cuprinse în contextul scrisorii sînt redate prin adecvarea conținutului la etapele convenționale ale compoziției epistolare, iar ultima parte cuprinde urarea "Şi să afle aiasta scrisoare a mea sănătoş pre dumeavoastră, o Gospodi, amin” și iscălitura finală „Feciorul vostru Cocrişel".

În ciuda caracterului pronunțat fatic al convențiilor scrisului epistolar, scrisoarea are o evidentă funcție emotivă. Ea se dezvoltă ca o confesiune care, prin tonul dramatic adoptat, își propune să sensibilizeze, iar naturalețea și sinceritatea transpar din opțiunile de expresie ce apropie textul scris de limba vorbită: „mă mănîncă lutul și păduchie”; „mor de dorol vostru”; „barbă pînă-n brîu”. Este, așadar, o perioadă culturalistorică în care scrisoarea personală îmbină stilul familiar propriu diverselor sale conţinuturi cu nota de oficialitate dată de aspectele formale specifice epistolei medievale. 
În general, în spațiul comunicării private, acolo unde epistola își afirmă caracterul intim și relativa eliberare de convenții, rolul ei de intermediar între două persoane aflate în imposibilitatea comunicării faţă în faţă pune în lumină diferite ipostaze ale epistolierului, iar pe unele dintre acestea istoria scrisorilor le va reține mai tîrziu ca prototipice: epistolierul în ipostaza soldatului plecat pe front, a omului privat de libertate, epistolierul în corespondența cu familia, cu prietenii sau în ipostaza îndrăgostitului.

\subsubsection{Canalul și codul}

Canalul comunicativ propriu scrisorii este cel scris. Majoritatea scrisorilor păstrate din perioada medievală românească nu sînt scrieri autografe și, deși lexicul epistolelor înregistrează foarte frecvent formele verbale la persoana I scriu/scriem, forma lor finală și respectarea normelor de redactare se datorează de obicei nu emitentului, ci scribului care devine astfel intermediar între interlocutori. Identitatea acestuia este semnalată în corpul scrisorii prin structuri precum „† Tănasie <a scris>” (DRH A, XXI/399), introduse la nivelul protocolului final. În general, suportul material al epistolei este hîrtia, pergamentul fiind utilizat rar, în redactarea actelor solemne, în special a celor întocmite în limba slavonă. O observație ce merită reținută este aceea că în perioada asupra căreia ne-am îndreptat atenția este destul de frecvent obiceiul de a actualiza două canale, cel scris și cel oral, în cadrul aceluiași demers comunicativ cu caracter oficial. Preferința transmiterii prin viu grai a mesajelor importante este o strategie politică a domnilor medievali și, implicit, o particularitate a corespondenței diplomatice din perioada respectivă. Fragmente precum „t Rogu-mă măriei tale să crezi pre omul nostru, pre Gligorie postealnicul, de ce va grăi." (Chivu et al., 1979, p. 110) vor deveni, cu trecerea timpului, tot mai rare.

Am observat, în prima parte a secțiunii 3 (Milică \& Morcov, 2016), că parcursul cultural al scrisului epistolar românesc a fost, la început, jalonat de tutela unor modele străine, cel mai important ca intensitate de manifestare și ca putere de influențare fiind modelul slavon. În secolul al XVI-lea obiceiului de a întocmi scrisori în acord cu tipare străine i se adaugă și inițiativa de a redacta în limba română corespondența oficială și cea particulară. Abia în secolul al XVII-lea limba română iș̦i afirmă supremația în scrisul epistolar, însă, chiar și în această perioadă, textele resimt influența timpului îndelungat în care modelul slavon a dominat scrisul autohton, iar îmbinarea celor două coduri, slavon și român, în cadrul aceluiași act comunicativ se manifestă ca trăsătură definitorie în epocă. Este frecvent obiceiul—expresie a ritualizării fatice a comunicării epistolare-de a introduce în protocolul inițial și în cel final elemente slavone, chiar dacă cea mai mare parte a epistolei este redactată în limba română. Faptul că intitulația (mai ales în epistolele domnești), locul și momentul scrierii și, uneori, urarea finală și identitatea scribului-aşadar elementele cu structură fixă—sînt redate în limba slavonă evocă ideea de formular menit să simplifice actul redactării.

Treptat, vechea limbă de cultură își limitează aria de dominare funcțională prin restrîngere la prezența în unele documente emise de autoritatea domnească, fapt ce indică, pe de o parte, deprinderea de a recurge la tiparele modelului tutelar, și, pe de altă parte, o strategie de a amplifica potențialul persuasiv al cărților domnești. În preajma secolului al XVII-lea, codul slavon este păstrat în virtutea tradiției și pentru a conferi solemnitate documentului de cancelarie, în special în redactarea unor hrisoave domnești ce consemnează donații, asigurarea unor drepturi etc. De altfel, arenga, podoabă retorică a diplomaticii, din ce în ce mai rară în documentele epocii, este valorificată doar în astfel de cărți elaborate integral în limba slavonă, care se bucură, în plus, de un suport material elegant și prețios cum este pergamentul. Astfel, într-o perioadă în care scrierile în limba română își afirmă funcționalitatea în diverse domenii de activitate, în spațiul public sau privat, slavona devine adesea semn al unei solemnităţi de sorginte religioasă.

\section{Bibliografie}

*** (1964) Rhetorica ad Herennium [Ad C. Herennium de ratione dicendi], with an English translation by Harry Caplan, William Heinemann Ltd., London, Harvard University Press, Cambridge, Massachusetts.

Aristotel (2004). Retorica, ediție bilingvă, traducere, studiu introductiv și index de Maria-Cristina Andrieș, note și comentarii de Ștefan-Sebastian Matei, Editura Iri, București.

Bly, R. W. (2004). Webster's New World Letter Writing Handbook, Wiley Publishing Inc., Indianapolis, IN. 
Bühler, K. (2011). Theory of Language. The Representational Function of Language, translated by Donald Fraser Goodwin in collaboration with Achim Eschbach, John Benjamins Publishing Company, Amsterdam - Philadelphia, Crossref.

Chițimia, I. C. \& Toma, S. (coord.) (1984). Crestomație de literatură română veche, vol. I, Editura Dacia, Cluj-Napoca.

Chivu, Gh. (2000). Limba română de la primele texte până la sfârşitul secolului al XVIII-lea. Variantele stilistice, Editura Univers Enciclopedic, București.

Chivu, Gh., Georgescu, M., Ioniță, M., Mareș, Al. \& Roman Moraru, A. (eds) (1979). Documente și însemnări românești din secolul al XVI-lea, Editura Academiei R.S.R., București.

Cicero (1973). Opere alese, ediție îngrijită de G. Guțu, vol. II, Editura Univers, București.

Donescu, C. (1840). Epistolariu culesu shi întocmitu asfelu, Tipografia lui Eliad, București.

Dumistrăcel, S. (2007). Limbajul publicistic din perspectiva stilurilor funcţionale, Editura Institutul European, Iași.

DRH A = Documenta Romanie Historica. A. Moldova, Editura Academiei Române, Bucureşti, 1969-2006.

DRH B = Documenta Romanie Historica. B. Țara Românească, Editura Academiei Române, Bucureşti, 1965-2006.

DRH C = Documenta Romanie Historica. C. Transilvania, Editura Academiei Române, București, 1981.

Iorga, N. (1925). Scrisori de boieri. Scrisori de Domni, Aşezămîntul tipografic “Datina Românească”, Vălenii de Munte.

Iorga, N. (2011). Scrisori de femei, Editura Vremea, Bucureşti.

Irimia, D. (1999). Introducere în stilistică, Editura Polirom, Iași.

Jakobson, R. (1964). Lingvistică și poetică. Aprecieri retrospective și considerații de perspectivă, în Probleme de stilistică, traducere de Mihail Nasta în colaborare cu Matei Călinescu, Editura Științifică, București, p. 83-125.

Jeffreys, E.M. \& Kazhdan, A.P. (1991). Epistolography, în Kazhdan, A.P. (ed.), The Oxford Dictionary of Byzantium, vol. I, Oxford University Press, Oxford - New York, p. 718-720, Crossref.

Mack, P. (2011). Letter-Writing Manuals, în A History of Renaissance Rhetoric 1380-1620, Oxford University Press.

Metzeltin, M. \& Thir, M. (2013). Antropologia textului, traducere în limba română de Octavian Nicolae, Editura Universităţii „Alexandru Ioan Cuza”, Iaşi.

Milică, I. (2014). Noțiuni de stilistică, Editura Vasiliana '98, Iași.

Milică, I. (2015). Funcțiile stilului în retorica creștină a Sf. Augustin, în „Diacronia”, nr. 1, 13 ian., art. A7, Crossref.

Milică, I. \& Morcov, I. (2016). Scrisul epistolar românesc: o perspectivă cultural-retorică (I), în „Diacronia”, nr. 3, 12 feb., art. A39, Crossref.

Murphy, J.J. (2001). Rhetoric in the Middle Ages. A History of the Rhetorical Theory from Saint Augustine to the Renaissance, Arizona Center for Medieval and Renaissance Studies, Tempe, AZ.

Troubetzkoy, N.S. (1949). Principes de phonologie, traduits par J. Cantineau, Librairie C. Klincksieck, Paris.

Urzescu, V. (1840). Epistolar sau modele de scrisori pentru tot felul de trebuințe, cules din cei mai vestiți autori noi și vechi, franțezi și alți cu formulele politeții moderne..., Tipografia Pitarului Constandin Pencovici, București.

Vârgolici, N. (2009). Redactare și corespondență, Editura Universității din București, București. 